\title{
Increasing Knowledge of Biodiversity on the Orphan Seamount: A New Species of Tedania (Tedaniopsis) Dendy, 1924
}

\author{
Pilar Ríos ${ }^{*}$, Javier Cristobo', Emily Baker ${ }^{2}$, Lindsay Beazley², Timothy Culwick ${ }^{3}$ and \\ Ellen Kenchington ${ }^{2}$
}

${ }^{1}$ Centro Oceanográfico de Gijón, Instituto Español de Oceanografía, Madrid, Spain, ${ }^{2}$ Department of Fisheries and Oceans, Bedford Institute of Oceanography, Dartmouth, NS, Canada, ${ }^{3}$ School of Earth Science, University of Bristol, Bristol, United Kingdom

\section{OPEN ACCESS}

Edited by:

Daphne Cuvelier, Center for Marine and Environmental

Sciences (MARE), Portugal

Reviewed by: Merrick Ekins,

Queensland Museum, Australia Jose Cruz-Barraza,

National Autonomous University of Mexico, Mexico

*Correspondence:

Pilar Ríos

pilar.rios.lopez@gmail.com; pilar.rios@ieo.es

Specialty section:

This article was submitted to Deep-Sea Environments and Ecology, a section of the journal

Frontiers in Marine Science

Received: 30 September 2020 Accepted: 14 January 2021

Published: 16 February 2021

Citation:

Ríos P, Cristobo J, Baker E,

Beazley L, Culwick T and Kenchington E (2021) Increasing

Knowledge of Biodiversity on the Orphan Seamount: A New Species of Tedania (Tedaniopsis)

Dendy, 1924

Front. Mar. Sci. 8:612857. doi: 10.3389/fmars.2021.612857
A new Tedania species (Porifera) was collect using remotely operated vehicles during the Canadian mission HUD2010-029 and the British RRS Discovery Cruise DY081, on the Orphan Seamount near the Orphan Knoll, northwest Atlantic, between 2999.88 and $3450.4 \mathrm{~m}$ depth. Orphan Knoll is an isolated, drowned continental fragment $550 \mathrm{~km}$ northeast Newfoundland in the Labrador Sea. This region is biologically rich and complex and in 2007, the regional fisheries management organization operating in the area regulated that no vessel shall engage in bottom-contact fishing activities until reviewed in 2020 with a review slated at the end of this year. Members of the genus Tedania are uncommon in the temperate northern hemisphere with only six species known previously: Tedania (Tedania) anhelans; Tedania (Tedania) pilarriosae; Tedania (Tedania) suctoria; Tedania (Tedania) urgorrii; Tedania (Tedaniopsis) gurjanovae; and Tedania (Tedaniopsis) phacellina. The particular features of the new sponge we describe are the very peculiar external morphology which is tree-like with dichotomous branching - a morphology not previously described in this subgenus; and the combination of spicules found: long styles, the typical tornotes of the subgenus and two sizes of onychaetes. Additional information is provided on other species of Tedaniopsis described from the Atlantic Ocean. Based on the characteristics reported, we propose a new species, Tedania (Tedaniopsis) rappi sp. nov. in honor of Prof. Hans Tore Rapp (1972-2020), University of Bergen, Norway, a renowned sponge taxonomist and coordinator of the Horizon 2020 SponGES project. The holotype of T. (T.) phacellina Topsent, 1912 from the Azores, the only other northern Atlantic species in the subgenus Tedaniopsis, was reviewed for comparison.

Keywords: sponges, VMEs, taxonomy, new species, Tedania (Tedaniopsis) rappi

\section{INTRODUCTION}

Orphan Knoll is an isolated, drowned continental fragment $550 \mathrm{~km}$ northeast of Newfoundland in the Labrador Sea (NW Atlantic) (Meredyk et al., 2020). The top of Orphan Knoll stands at $1,800-2,000 \mathrm{~m}$ and is marked by a series of protruding mounds at depths of between 1,800 and 2,300 $\mathrm{m}$. The Orphan Seamount is located $9 \mathrm{~km}$ northeast of the southern-most extension of Orphan Knoll and is a volcanic seamount (Meredyk, 2017). Physical properties indicate that 
mid-depth waters above Orphan Knoll are in a boundary region between outflow from the Labrador Sea (subpolar gyre) and northward flow of the North Atlantic Current (subtropical gyre). Near-bottom current measurements provide evidence for anticyclonic (clockwise) circulation around the knoll (Greenan et al., 2010) that could have impacts on the benthic communities. The Orphan Basin-Orphan Knoll region is biologically rich and complex (Wudrick et al., 2020), and strongly influenced by local processes and advection.

By the Northwest Atlantic Fisheries Organization (NAFO) to protect coral, sponges and other vulnerable marine ecosystems from impact by bottom contact fishing gear. Orphan Knoll is also considered an Ecologically or Biologically Significant Area (EBSA) by the Convention on Biological Diversity (2015).

In 2010, Fisheries and Oceans Canada (DFO) in collaboration with academic partners conducted a multidisciplinary oceanographic survey of Flemish Cap and Orphan Knoll onboard the CCGS Hudson in support of the identification and characterization of vulnerable marine ecosystems as part of Canada's contribution to the NEREIDA program (NAFO, 2016).

On Orphan Knoll and its associated seamount (Orphan Seamount), the remotely operated vehicle (ROV) ROPOS was used to collect high-resolution continuous video and digital still images of Orphan Knoll's diverse benthic communities and geological landscape. Specimen samples were collected using the manipulator arm of ROPOS to serve as taxonomic voucher specimens. We augment data collected during this survey with samples collected during the Isotope CYcling in the LABrador Sea (ICY-LAB) mission onboard RRS Discovery in 2017. The overall aim of that mission was to understand nutrient and isotope cycling regions of the Labrador Sea and Greenland fjords (Hendry et al., 2019).

During dive number 1340 by ROV ROPOS at Orphan Seamount, the holotype of the new species was collected. The transect took place between depths of 1,862 and 3,004 m, with an average of 2,455 $\mathrm{m}$ and a distance traveled of $11,515 \mathrm{~m}$ (Wudrick et al., 2020). This new species of the genus Tedania Gray, 1867, was collected close to 3,000 $\mathrm{m}$ in depth, inside the NAFO closed area and CBD EBSA, where the substrate were rocks of volcanic origin (Meredyk et al., 2020).

The genus Tedania is cosmopolitan and comprises 83 species, with 29 of them distributed in the northern hemisphere (Van Soest et al., 2021). Tedania is characterized by having diactinal ectosomal tornotes, or tylotes, usually provided with spines on the tyles, or smooth oxea-like spicules with mucronate apices. Choanosomal megascleres are styles with smooth or microspined bases and the microscleres are onychaetes that characterize the Family Tedaniidae Ridley and Dendy, 1886. The choanosomal megascleres (styles) are arranged in plumose, reticulate, plumoreticulate or dendritic columns in the genus Tedania and the ectosomal skeleton is tangential or paratangential.

The genus Tedania had been subdivided into different subgenera. Desqueyroux-Faúndez and Van Soest (1996) followed by Van Soest (2002) created a subgeneric classification of Tedania with three subgenera: Tedania, Tedaniopsis, and Trachytedania. The last one is considered currently to be a valid genus (Cristobo and Urgorri, 2001; Van Soest, 2017) and is characterized by species having acanthostyles as choanosomal megascleres. Recently, a third subgenus was recognized, Stylotedania Van Soest, 2017 and nowadays the World Porifera Database (Van Soest et al., 2021) consider again three valid subgenera: Tedania Gray, 1867, Tedaniopsis Dendy, 1924, and Stylotedania Van Soest, 2017. The first one, differentiates those species of genus Tedania with ectosomal diactinal spicules with smooth or microspined heads, choanosomal monactinal or diactinal spicules and onychaetes. The second differentiates those where the ectosomal diactinal spicules have smooth heads, the choanosomal spicules are monactinal or diactinal and the typical onychaetes are present. The third differentiates those in which the ectosomal and choanosomal spicules are monactinal, diactinal spicules being absent and also have onychaetes (Van Soest, 2017; Aguilar-Camacho et al., 2018).

\section{MATERIALS AND METHODS}

Sampling was carried out on board the CCGS Hudson using the remotely operated vehicle ROPOS, in July 2010 during mission HUD2010-029 and on the RRS Discovery Cruise DY081 with the ROV ISIS, in July 2017. During the Hudson mission, a single specimen was collected using the manipulator arm of ROPOS at $2999.88 \mathrm{~m}$ depth from Orphan Seamount (Figure 1) and stored in its "biobox" until the ROV surfaced. A Seabird 49 CTD attached to this ROV provided temperature $\left(2.1^{\circ} \mathrm{C}\right)$ and salinity $(34.89 \% 0)$ data at the time of collection. During the RRS Discovery cruise, sponges were collected either using the manipulator arms, or using a suction system. Upon recovery of the ROV to the surface, samples were transferred to buckets and taken into a wet lab for processing. Then, each sponge sample was labeled, measured and photographed.

The specimen from ROPOS was immediately preserved in $70 \%$ ethanol upon surfacing. The sample from ROV ISIS was carried in pre-chilled seawater into the cold room $\left(4^{\circ} \mathrm{C}\right)$ to commence sampling triage and was preserved in 95\% ethanol.

Details of the specimens examined are deposited in PANGAEA $^{\circledR}$ Data Publisher ${ }^{1}$ under the digital object identifier (DOI): https://doi.pangaea.de/10.1594/PANGAEA.924814

For the study of dissociated spicules, the organic matter was digested in sodium hypochlorite following the methods of Rapp (2006) and Cárdenas and Rapp (2012) and digested in nitric acid for SEM, following methods described in Cristobo et al. (1993). Spicules and skeleton were coated with gold-palladium using an Emscope Sputter coater SC 500 and examined with a Hitachi S570 SME at Station Marine d'Endoume (France) and a JEOL-JSM$6610 \mathrm{LV}$ of the Oviedo University. The data for spicule sizes are based on 25 measurements for each spicule category, comprising minimum, maximum and average lengths in micrometers $(\mu \mathrm{m})$. A light microscope (Nikon Eclipse 50i with a Nikon DS-Fi1 camera) was used. The skeleton was also photographed with the same camera system and stacking performed using the Helicon Focus program (129 images).

\footnotetext{
${ }^{1}$ www.pangaea.de
} 


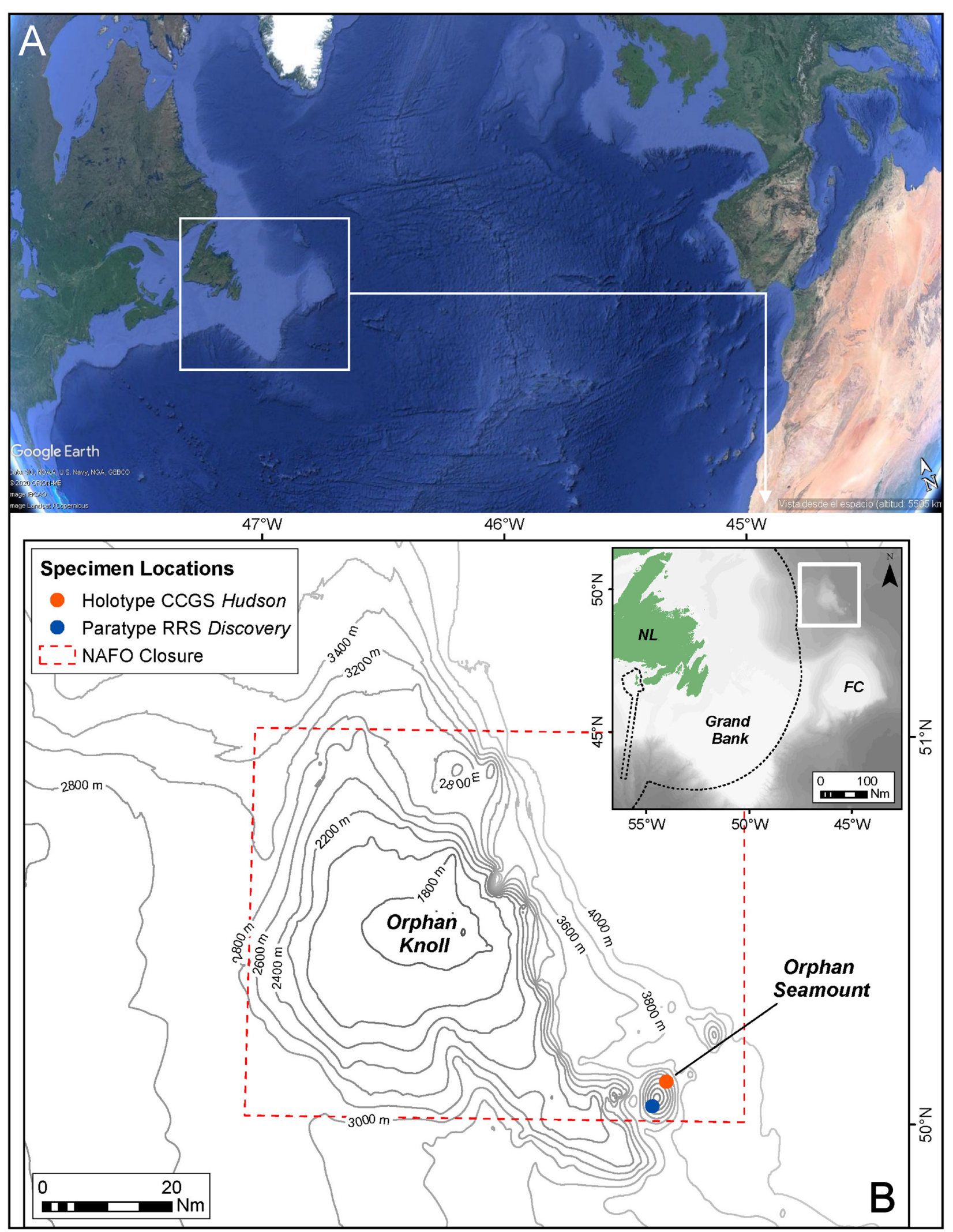

FIGURE 1 | Location of sampling sites of new species. (A) Situation of Orphan Knoll in the North Atlantic (from Google Earth). (B) Positions of specimens locations (Holotype and Paratype) on Orphan Seamount. 

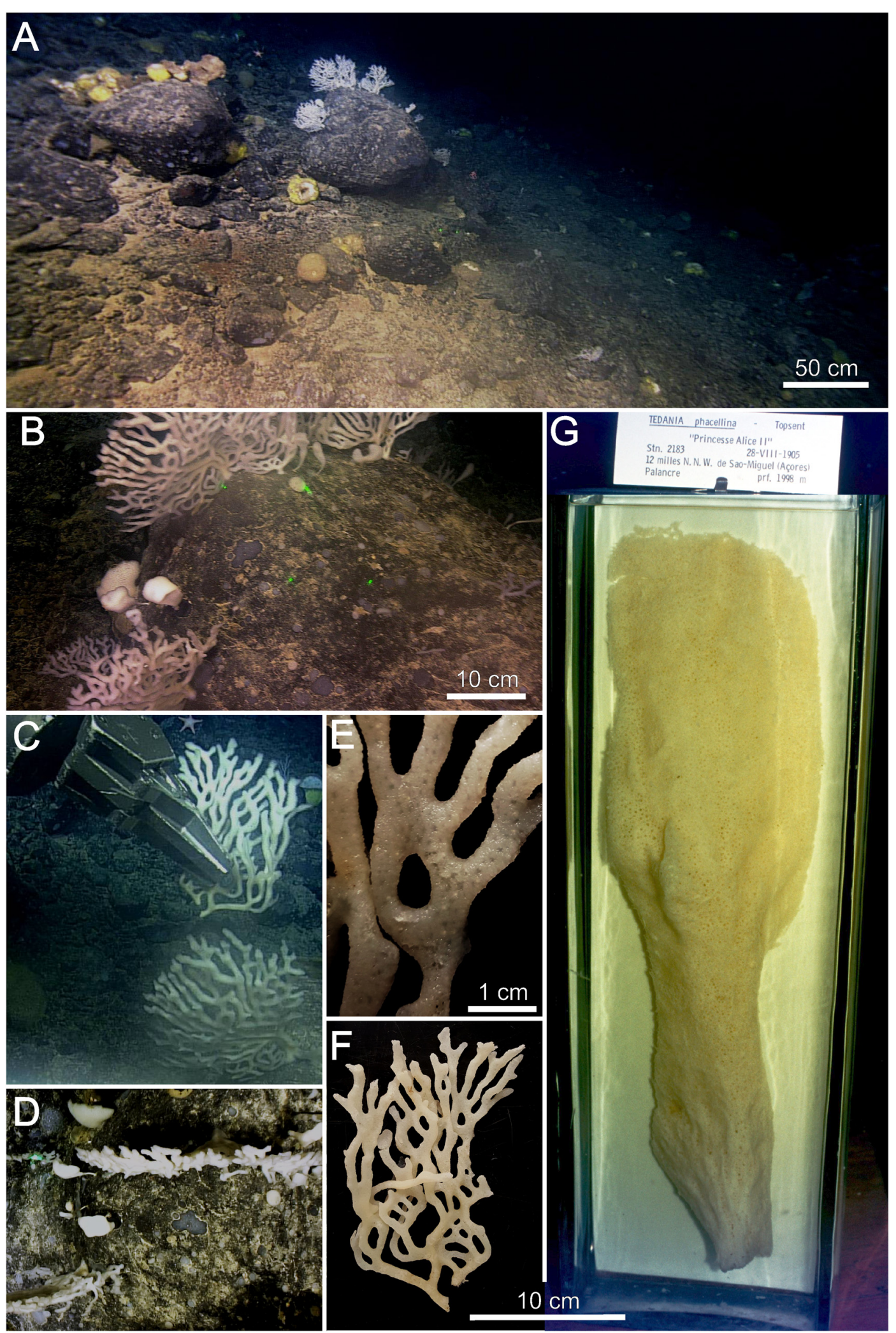

FIGURE 2 | Tedania (Tedaniopsis) rappi sp. nov. (A,B) Environment of holotype. (C) In situ collection of holotype. (D) View of two specimens from the downward facing camera. (E) Detail of the surface of the holotype on which the oscula are seen. (F) Holotype. (G) Tedania (Tedaniopsis) phacellina, Topsent's holotype located in the display cases of the Oceanographic Museum of Monaco. Note that figures (F,G) are on the same scale to compare the proportions and shapes of both species. 

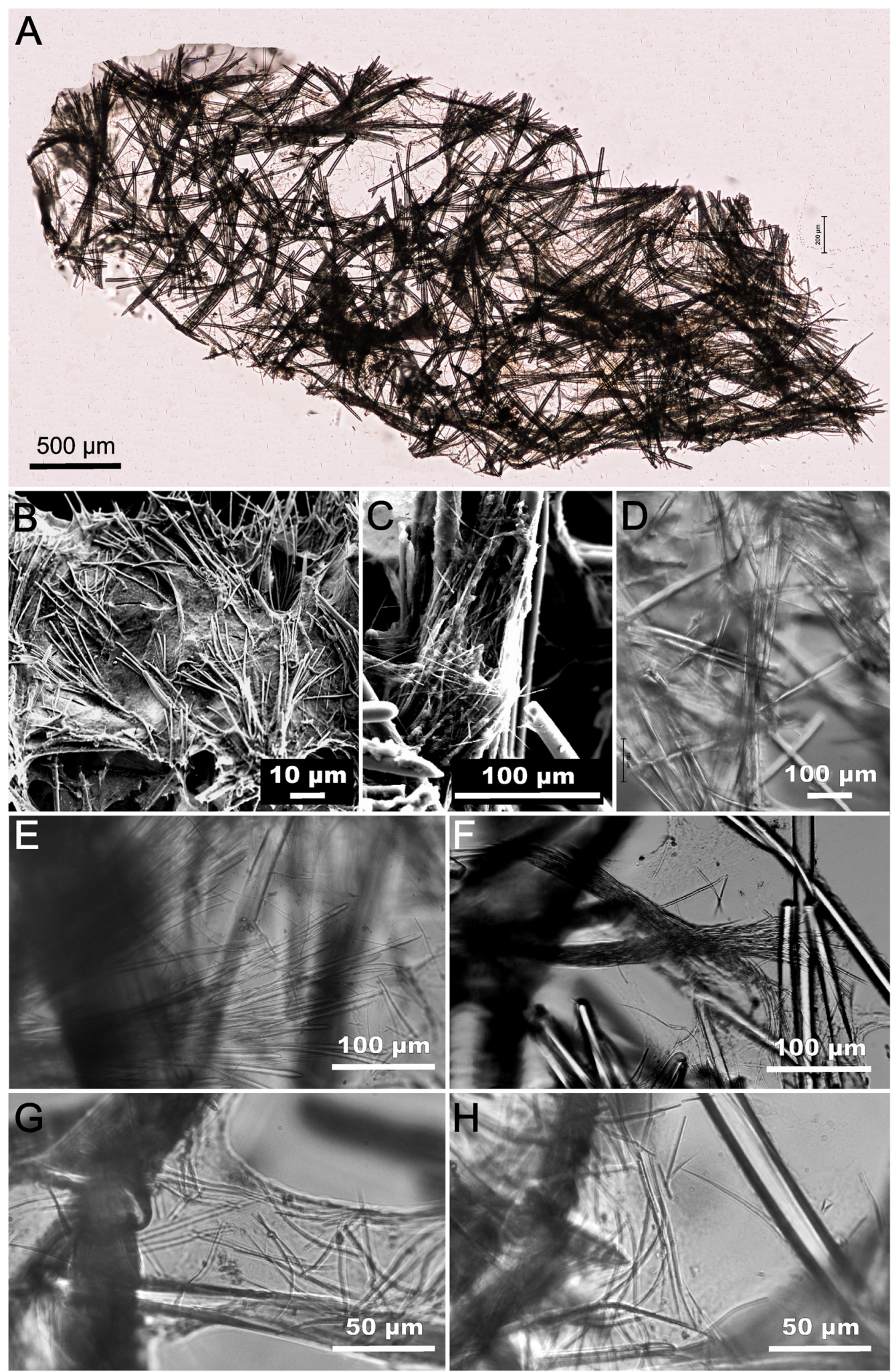

FIGURE 3 | Tedania (Tedaniopsis) rappi sp. nov. (A) Transversal section of a branch of holotype (light microscope, LM). (B) Scanning Electron Microscope (SEM) picture of the surface of sponge ectosomal tornotes protruding. (C) Detailed picture of group of onychaetes in choanosome (SEM). (D) Bundle of styles in choanosome (LM). (E) Bundles of tornotes projected in bouquets in the ectosome (LM). (F) Two trichodragmata in the ectosome (LM). (G) Onychaetes within a spongin fiber (LM). (H) Onychaetes in the choanosome (LM). 
DNA was extracted from the holotype using a Qiagen DNeasy Blood and Tissue Kit (QIAgen) following an adapted version of the protocol provided by the manufacturer (overnight incubation in lysis buffer and proteinase $\mathrm{K}$ ). We selected two molecular markers to amplify, $18 S$ rDNA (18S) and $28 S$ rDNA (28S). The complete $18 \mathrm{~S}(1,766 \mathrm{bp})$ was amplified in three legs using the primers 1F-5R, 4F-7R, and a.20-9R (Giribet and Wheeler, 2001), and a fragment of $589 \mathrm{bp}$ of $28 \mathrm{~S}$ (D6 - D8 region) was amplified using the primers CMPOR1490F and CMPOR2170R (Morrow et al., 2012). D6 - D8 region was selected because these where the most successful PCRs regarding 28S. All $18 \mathrm{~S}$ fragments were amplified using the PCR protocol $94^{\circ} \mathrm{C}, 5 \mathrm{~min} ;\left(94^{\circ} \mathrm{C}, 1 \mathrm{~min}\right.$, $\left.52^{\circ} \mathrm{C}, 1 \mathrm{~min}, 72^{\circ} \mathrm{C}, 1 \mathrm{~min}\right) \times 38$ cycles; $72^{\circ} \mathrm{C}, 10 \mathrm{~min} . \mathrm{We}$ used a different protocol for $28 \mathrm{~S}$ of $94^{\circ} \mathrm{C}, 5 \mathrm{~min} ;\left(94^{\circ} \mathrm{C}, 1 \mathrm{~min}\right.$, $\left.55^{\circ} \mathrm{C}, 1 \mathrm{~min}, 72^{\circ} \mathrm{C}, 1 \mathrm{~min}\right) \times 38$ cycles; $72^{\circ} \mathrm{C}, 10 \mathrm{~min}$. All DNA markers were amplified in $12.5 \mu \mathrm{L}$ reactions using 10.5 $\mu L$ of VWR Red Taq DNA Polymerase 1.1× Master Mix (VWR International bvba/sprl, Belgium), $0.5 \mu \mathrm{L}$ of the forward and reverse primers, and $1 \mu \mathrm{L}$ of DNA template. PCR products, stained with GelRed $^{\circledast}$ (Biotium, United States), were visualized in a $2.5 \%$ agarose gel electrophoresis, run at $90 \mathrm{~V}$ for $30 \mathrm{~min}$. Sequencing was conducted on an ABI 3730XL DNA Analyser (Applied Biosystems, United States) at the Molecular Core Labs (Sequencing Facility) of the NHMUK, using the forward and reverse primers mentioned above. The DNA was degraded and the results were negative, probably because the genomic DNA loses quality in depth water samples (Kersken et al., 2018).

The electronic version of this article in PorTable Document Format (PDF) will represent a published work according to the International Commission on Zoological Nomenclature (ICZN), and hence the new names contained in the electronic version are effectively published under that Code from the electronic edition alone. This published work and the nomenclatural acts it contains have been registered in ZooBank, the online registration system for the ICZN. The ZooBank Life Science Identifiers (LSIDs) can be resolved and the associated information viewed through any standard web browser by appending the LSID to the prefix http://zoobank.org/. The LSID for this

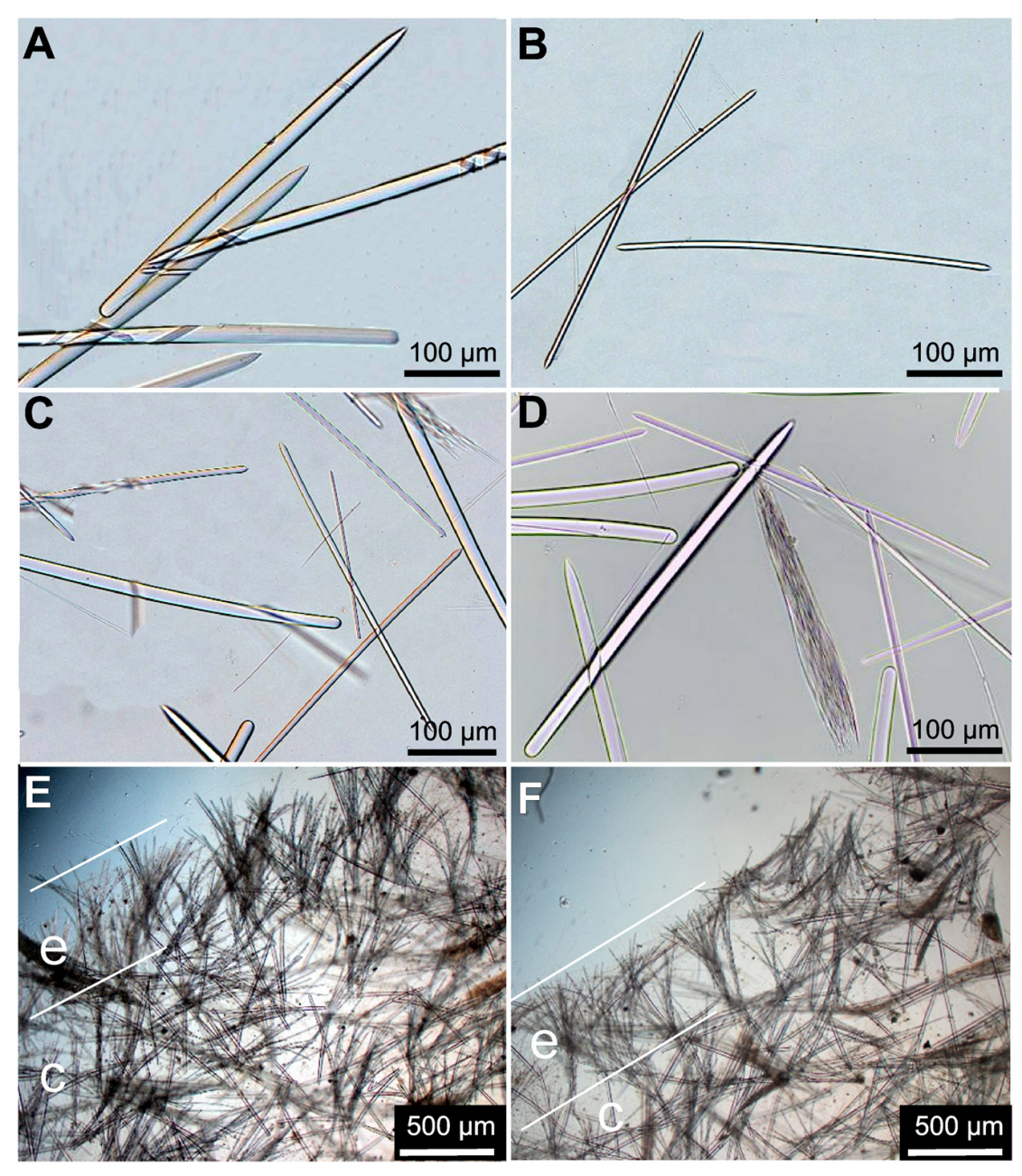

FIGURE 4 | Spicules of Tedania (Tedaniopsis) rappi sp. nov. (Paratype) as seen with a light microscope. (A) Styles. (B) Tornotes. (C) Different kinds of spicules. (D) Group of onychaetes in tricodragmata formation. (E,F) Skeleton with marked differentiation between ectosome (e) and choanosome (C). 
publication is: urn:lsid:zoobank.org:pub:687D7886-46D4-461A8799-2B76BB446D0C.

Global subgenus maps were derived from data provided by the World Porifera Database (Van Soest et al., 2021).

\section{RESULTS}

In this study we analyzed a new species of the Tedaniopsis subgenus collected in Orphan Seamount and re-examined Tedania (Tedaniopsis) phacellina Topsent, 1912 from Azores for comparison. This material is described and illustrated. The new species described here has the taxonomic authority restricted to Ríos, Cristobo, and Kenchington.

Systematics follow the SystemaPorifera (Hooper and Van Soest, 2002) chapter on Family Tedaniidae (Van Soest, 2002) and Morrow and Cárdenas (2015).

Phylum PORIFERA Grant, 1836

Class DEMOSPONGIAE Sollas, 1885

SubClass HETEROSCLEROMORPHA Cárdenas et al., 2012

Order POECILOSCLERIDA Topsent, 1928

Family TEDANIIDAE Ridley and Dendy, 1886

Genus Tedania Gray, 1867

Definition: Tedaniidae with differentiated ectosomal and choanosomal megascleres Van Soest (2002).

Subgenus Tedaniopsis Dendy, 1924

Diagnosis: Tedania with relatively long thick, smooth styles, occasionally modified to anisostrongyles or anisoxeas, as structural megascleres. Ectosomal megascleres are mucronate or tylostrongylote tornotes occasionally with one or more vestigial spines (Desqueyroux-Faúndez and Van Soest, 1996).

Tedania (Tedaniopsis) rappi Ríos, Cristobo and Kenchington sp. nov.

Type material: Holotype: TBD Orphan Seamount (NW Atlantic), 50.1119; -45.3199. Depth 2999.88 m, Coll. CCGS Hudson, 19.07.2010, 1 specimen. Rock substrate. In 70\% Ethanol Canadian Museum of Nature number CMNI 20200004. Paratype: Atlantic Reference Centre (ARC) Museum (ARC 81604) Orphan Seamount (NW Atlantic), 50.0484; 45.3757, 3,450 m depth, Coll. RRS Discovery, 08.07.2017, 1 specimen. Rock substrate. In $100 \%$ Ethanol.

Holotype of Tedania (Tedaniopsis) phacellina Topsent, 1912, was revised. Museé Oceanographique Monaco; Collection of S.A.S. Le Prince de Monaco Station 2183, 28th August 1905, 1,998 $\mathrm{m}$ in depth. A small fragment (Schizotype) was analyzed by SEM.

Derivatio nominis: In honor of Prof. Hans Tore Rapp (1972-2020), University of Bergen, Norway, a renowned sponge taxonomist and dear colleague, who described 50 new species of sponges for science. Prof. Rapp was also coordinator and leader of the EU Horizon 2020 SponGES project which focused much needed attention on deep-sea sponges and their habitats.

\section{Description}

The habitus of the new species is arborescent, erect, branching, tree-like in appearance, flat, fan-shaped, it grows in one plane (bidimensional structure, Figure 2D). Size: $25 \mathrm{~cm}$ (width) $\times$ $15 \mathrm{~cm}$ (height). Attached to the substrate by a short and single peduncle $[1 \mathrm{~cm}$ (width) $\times 2 \mathrm{~cm}$ height $]$ from which it branches mainly in dichotomous arrangement; often, the branches anastomose between them (Figures 2B,E). The ends of each branch are rounded (Figure 2). The holotype (half of the whole specimen) measures $19 \mathrm{~cm}$ long and $12 \mathrm{~cm}$ wide (Paratype $6.5 \times 6 \mathrm{~cm}$ ). Each branch is elliptical in section from 5 to $9 \mathrm{~mm}$. Slightly velvety surface with pores (oscules $<1 \mathrm{~mm}$ diameter) arranged in regular distribution along branches. Consistency flexible and elastic. Color in life and in preservation white.

\section{Skeleton}

The choanosomal skeleton is a loose reticulation of bundles of 2-5 styles (paucispicular) with weaker interconnections of 1-2 spicules cemented with spongin (Figures $3 \mathbf{A}, \mathbf{B}, \mathbf{D})$. The ectosomal skeleton consists of bundles of tornotes that are projected in bouquets to the surface (Figure 3E). Onychaetes, of two sizes, are scattered in the choanosome and within spongin fibers (Figures 3G,H). Both size classes of onychaetes can be placed among the tornotes of the ectosomal skeleton and frequently in tricodragmata (Figure 3F).

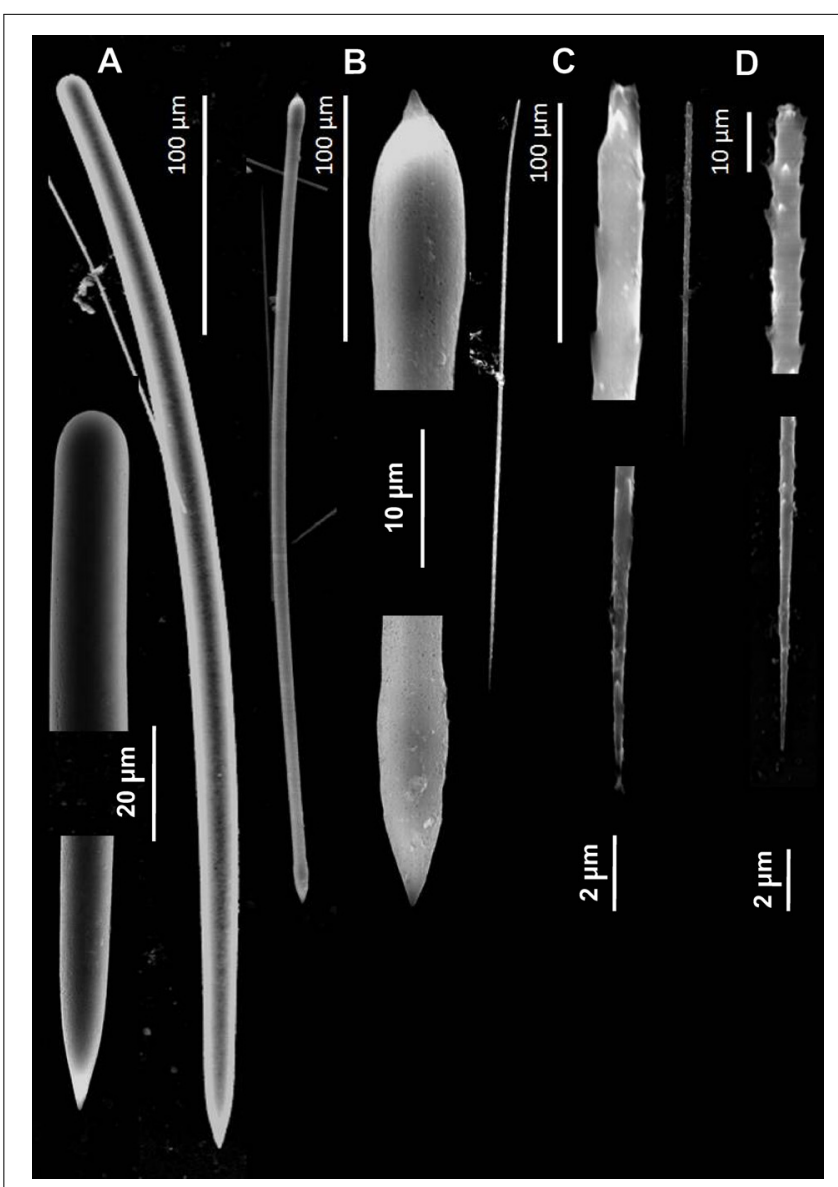

FIGURE $\mathbf{5}$ | Spicules of Tedania (Tedaniopsis) rappi sp. nov. (Holotype) as seen with a Scanning Electron Microscope. (A) Styles. (B) Tornotes. (C) Onychaetes I. (D) Onychaetes II. 


\section{Spicules Styles, Tornotes, and Onychaetes}

Styles (Figures 4A,B, 5A). Straight or slightly curved near the basal end with a sharp point in the apical end. Uniform in length and thickness: $457.94(505) 554.64 \times 11.41(14.05) 17.41 \mu \mathrm{m}$ (Holotype). 406 (459) $504 \times 14$ (15.3) $17 \mu \mathrm{m}$ (Paratype).

Tornotes (Figures 4A-C, 5B) Anisotornotes, with slightly inflated and lanceolate ends one of them more mucronate than the other. Measurements: 363.13 (408.68) $440.400 \times 5.79$ (6.58) $7.42 \mu \mathrm{m}$ (Holotype). 379 (399.8) $422 \times 6$ (7.2) $8.6 \mu \mathrm{m}$ (Paratype).

Onychaetes of two sizes. The largest (I) are 203.3 (234.40) $268.02 \mu \mathrm{m}$ long (Holotype) 240 (268.3) $307 \mu \mathrm{m}$ long (Paratype) (Figures 4C, 5C). The smallest (II) are 67.85 (76.19) $86.28 \mu \mathrm{m}$ long (Holotype) 68 (79.8) $82 \mu \mathrm{m}$ long (Paratype) (Figures 3FH, 4C,D, 5C,D). The largest have uneven ends, one pointed and the other more or less rounded. The smaller ones have one end pointed and the other straight with 3-4 spines. We have observed the largest onychaetes grouped in trichodragmata (Figures 3, 4).

\section{Distribution and Ecology}

Orphan Seamount, where this new species was collected, is in a transition area between the Arctic and the Temperate Northern Atlantic ecoregions (Spalding et al., 2007). Specimens of the new species were seen in the slopes NE and SW of Orphan Seamount (Labrador Sea, NW Atlantic) attached to rocks of volcanic origin at $2,999-3,450 \mathrm{~m}$; the mean bottom temperature was of $2.39 \pm 0.03^{\circ} \mathrm{C}$.

On the rock where the holotype specimen was sampled, there were at least 10 specimens of the same species and 39 in the whole transect (ROV dive number 1340, 11,515 $\mathrm{m}$ in total distance on bottom). The most characteristic fauna associated with the habitat are other Porifera mainly belonging to genus Geodia which represents the highest biomass and the highest number of specimens of the sponge grounds, mainly due to G. phlegraei (Sollas, 1880), and also G. megastrella Carter, 1876, G. barretti Bowerbank, 1858, G. atlantica (Stephens, 1915), G. macandrewii Bowerbank, 1858, and G. hentscheli Cárdenas et al., 2010. Other frequent Porifera are Lissodendoryx (Lissodendoryx) complicata (Hansen, 1885), Hexadella detritifera Topsent, 1913, Stryphnus fortis (Vosmaer, 1885), and Polymastia corticata Ridley and Dendy, 1886. Also hexactinellids such as Farrea herdendorfi Duplessis and Reiswig, 2004, cup-like species such as Asconema fristedti Tabachnick and Menshenina, 2007, Chenolasma sp. and cylindrical species such as Dictyaulus romani Murillo et al., 2013 or representatives of the families Euplectellidae or Rosellidae were present. Other invertebrates included Cnidarians such as Bathypathes sp., representatives of the family Clavulariidae, Chrysogorgiidae, several species of Scleractinia, Anthomastus sp., Echinoderms and fishes. The total number of individuals of each taxon/morphotype, abundance by transect and a pictorial guide of megafauna can be seen in Wudrick et al. (2020).

\section{Remarks}

The most notable difference from other species of subgenus Tedaniopsis is the erect, tree-like appearance of this species, which has never been recorded before in this subgenus. Goodwin et al. (2012) and Aguilar-Camacho et al. (2018) compiled the data from the majority of species of this subgenus from the Antarctic and South Atlantic and worldwide respectively, and none have any features like the new species, being mostly massives, such as Tedania (Tedaniopsis) charcoti Topsent, 1907; T. (T.) armata

TABLE 1 | Spicule characteristics of Tedania (Tedaniopsis) species from the northern hemisphere.

\begin{tabular}{|c|c|c|c|c|c|c|c|}
\hline \multirow{3}{*}{$\begin{array}{l}\text { Specie } \\
T .(T .) \text { phacellina }\end{array}$} & \multicolumn{2}{|c|}{ Megascleres ( $\mu \mathrm{m})$} & \multirow{2}{*}{\multicolumn{2}{|c|}{$\begin{array}{c}\text { Microscleres }(\mu \mathrm{m}) \\
\text { Onychaetas }\end{array}$}} & \multirow[t]{3}{*}{ Habitus } & \multirow[t]{3}{*}{ Depth (m) } & \multirow[t]{3}{*}{ Distribution } \\
\hline & \multirow{2}{*}{$\begin{array}{l}\text { Choanosomal } \\
\text { Style }\end{array}$} & \multirow{2}{*}{$\begin{array}{l}\text { Ectosomal } \\
\text { Tornote }\end{array}$} & & & & & \\
\hline & & & Largest (I) & Smaller (II) & & & \\
\hline Topsent, 1912 & $515-550 \times 20-23$ & $440-470 \times 7$ & $290-330 \times 1.7$ & $70-80$ & Erect blade & 1,998 & Azores \\
\hline $\begin{array}{l}\text { Topsent, } 1912 \\
\text { re-measured (this } \\
\text { study) }\end{array}$ & $\begin{array}{l}\text { Styles I: } 384.64(471.65) \\
519.53 \times 9.55(16.78) 26.67 \\
N=25 \text { Styles II: } 438(467.90) \\
511.04 \times 5.7(7.55) 11.58 \\
N=7\end{array}$ & $\begin{array}{l}348.61(379.23) 408 \times \\
5.79(7.20) 9.27 N=25\end{array}$ & $\begin{array}{l}180.08(252.15) \\
285.26 N=25\end{array}$ & $\begin{array}{l}49.48(64.93) \\
85.89 N=25\end{array}$ & Erect blade & 1,998 & Azores \\
\hline \multicolumn{8}{|l|}{$T .(T$.$) gujarnovae$} \\
\hline Koltun, 1958 & $260-343 \times 8-14$ & $202-280 \times 4-8$ & $197-312 \times 2$ & $77-157 \times 3-4$ & $\begin{array}{l}\text { Cushion- } \\
\text { shaped }\end{array}$ & $60-100$ & $\begin{array}{l}\text { E Tatar Strait, } \\
\text { off Sakhalin, } \\
\text { USSR }\end{array}$ \\
\hline Bakus, 1964 & $296-373 \times 9-13$ & $204-252 \times 4-7$ & $142-265 \times 1.5-1.6$ & $\begin{array}{l}40-91 \times \\
2.2-3.5\end{array}$ & $\begin{array}{l}\text { Amorphous } \\
\text { encrusting } \\
\text { sponge }\end{array}$ & $73-198$ & $\begin{array}{l}\text { President } \\
\text { Channel and } \\
\text { San Juan } \\
\text { Channel, San } \\
\text { Juan } \\
\text { Archipelago }\end{array}$ \\
\hline \multicolumn{8}{|l|}{ T. (T.) rappi sp. nov. } \\
\hline Holotype & $\begin{array}{l}457.94(505) 554.64 \times 11.41 \\
(14.05) 17.41 N=25\end{array}$ & $\begin{array}{l}363.13(408.68) 440.44 \times \\
5.79(6.58) 7.42 N=25\end{array}$ & $\begin{array}{l}229.93(257.49) \\
277.22 N=25\end{array}$ & $\begin{array}{l}67.85(76.19) \\
86.28 N=25\end{array}$ & Tree-like & 2,999 & $\begin{array}{l}\text { Orphan } \\
\text { Seamount }\end{array}$ \\
\hline Paratype & $\begin{array}{l}406(459) 504 \times 14(15.3) 17 \\
N=25\end{array}$ & $\begin{array}{l}379(399.8) 422 \times \\
6(7.2) 8.6 N=25\end{array}$ & $\begin{array}{l}240(268.3) 307 \times \\
1(1.2) 2 N=25\end{array}$ & $\begin{array}{l}68(79.8) 82 \\
N=20\end{array}$ & Tree-like & 3,450 & $\begin{array}{l}\text { Orphan } \\
\text { Seamount }\end{array}$ \\
\hline
\end{tabular}


Sarà, 1978; T. (T.) corticata Sarà, 1978; T. (T.) laminariae Sarà, 1978; T. (T.) cristagalli Dendy, 1924; T. (T.) gracilis Hentschel, 1914; T. (T.) massa Ridley and Dendy, 1886; T. (T.) sarai Bertolino et al., 2007; T. (T.) tenuicapitata Ridley, 1881; T. (T.) vanhoeffeni Hentschel, 1914; globular such as T. (T.) gracilis Hentschel, 1914; T. (T.) lanceta Koltun, 1964; cup shaped such as T. (T.) turbinata (Dendy, 1924); T. (T.) infundibuliformis Ridley and Dendy, 1886; T. (T.) tantula (Kirkpatrick, 1907) or crust such as T. (T.) aurantiaca Goodwin et al., 2012 and T. (T.) wellsae Goodwin et al., 2012. The differences with respect to the two species from the northern hemisphere are also habitus, the spicule morphology and their ecology (Table 1). Topsent (1912) described Tedania (Tedaniopsis) phacellina from the NW São Miguel Island, in the Azores at 1,998 $\mathrm{m}$ in depth. Only one specimen was found and it has not been seen since, but it is a shallower species than the new one. Its shape is clearly different: T. (T.) phacellina, above its attachment, first rolls up into a cone, then, almost immediately, reopens to take the form of a vertical blade, flat and without branches. The blade is divided into two parts: the lower, narrow, in a fairly deep gutter; the upper one, longer, wider and slightly concave. It has the appearance of an oar paddle. T. (T.) rappi, as described above is branched, arborescent, and tree-like in appearance. Regarding the size, T. (T.) phacellina, is a large and robust sponge (47 cm high) (Figure 2).

Table 1 presents a comparison of the Tedania (Tedaniopsis) species from the northern hemisphere. Habitus is very different among them: Arborescent in the new species, cushion-shaped in T. (T.) gujarnovae and lamellate or cup-shaped in T. (T.) phacellina. Although they present a similar composition of the spicular types, differences between the three species can be appreciated. The styles of $T$. (T.) gujarnovae are clearly shorter (260-373 $\mu \mathrm{m})$ than in the new species $(406-554.6 \mu \mathrm{m})$. Those of $T$. (T.) phacellina, $(384-550 \times 9.5-26 \mu \mathrm{m})$ similar in length to $T$. (T.) rappi, however, they are much thicker (11.4-17.4 $\mu \mathrm{m}$ in the new) This is a remarkable difference. Also a second category of styles was found in the analysis of the holotype (Figures 6, 7); these are slightly thinner (5.7-11.5 $\mu \mathrm{m})$ and scarce. The ectosomal tornotes are shorter in T. (T.) gujarnovae (202-280 $\mu \mathrm{m})$ than in T. (T.) phacellina $(348.6-470 \mu \mathrm{m})$ and in $T$. (T.) rappi (363-440.4 $\mu \mathrm{m})$. In $T$ (T.) rappi tornotes are mucronate in one end while $T$. (T.) phacellina have a short end (conical). In $T$. (T.) phacellina the ends are slightly more swollen than in T. (T.) rappi; tornotes do not have lanceolate ends in T. (T.) gujarnovae. The largest onychaetes in T. (T.) gujarnovae $(142-312 \mu \mathrm{m})$ are also slightly smaller than in the other two species: T. (T.) rappi (229.9-307 $\mu \mathrm{m})$, T. (T.) phacellina (180$330 \mu \mathrm{m})$. However, the small onychaetes $(40-157 \mu \mathrm{m})$ are larger than in the other two species: T. (T.) rappi $(67.8-86.2 \mu \mathrm{m}), T$. (T.) phacellina (49.4-85.8 $\mu \mathrm{m})$.

In the three species, the bathymetric distribution is quite different: in shallower waters from the South Sakhalin and the South Kurile Island region, T. (T.) gujarnovae (60-190 m), T. (T.) phacellina from the Azores $(1998 \mathrm{~m})$ and the one that has been found deeper is T. (T.) rappi $(2999-3450 \mathrm{~m})$ from Orphan Seamount, in the North Western Atlantic.

A comparative table of all Tedania (Tedaniopsis) described species worldwide can be seen in Goodwin et al. (2012) and
Aguilar-Camacho et al. (2018). Therefore, the new species is characterized by the external appearance as tree-like with dichotomous branching, long styles, the typical tornotes of the subgenus with lanceolated ends and two sizes of onychaetes.

\section{DISCUSSION}

The principal reviews of the Tedania genus have been carried out by Bergquist and Fromont (1988); Desqueyroux-Faúndez and Van Soest (1996), Van Soest (2002), and Aguilar-Camacho et al. (2018). The genus Tedania actually contain 83 species (Van Soest et al., 2021), 60 of them are included in the Tedania subgenus, 21 in Tedaniopsis, 1 in Stylotedania and one more without a description-Tedania rubra Von Lendenfeld, 1888 synonymized with Tedania anhelans by Hooper and Wiedenmayer (1994) but it remains incertae sedis as the description of Lendenfeld is inadequate (added by Van Soest, 2010 in Van Soest et al., 2021).

Most species of the genus Tedania have been reported from the southern hemisphere (54). The subgenus

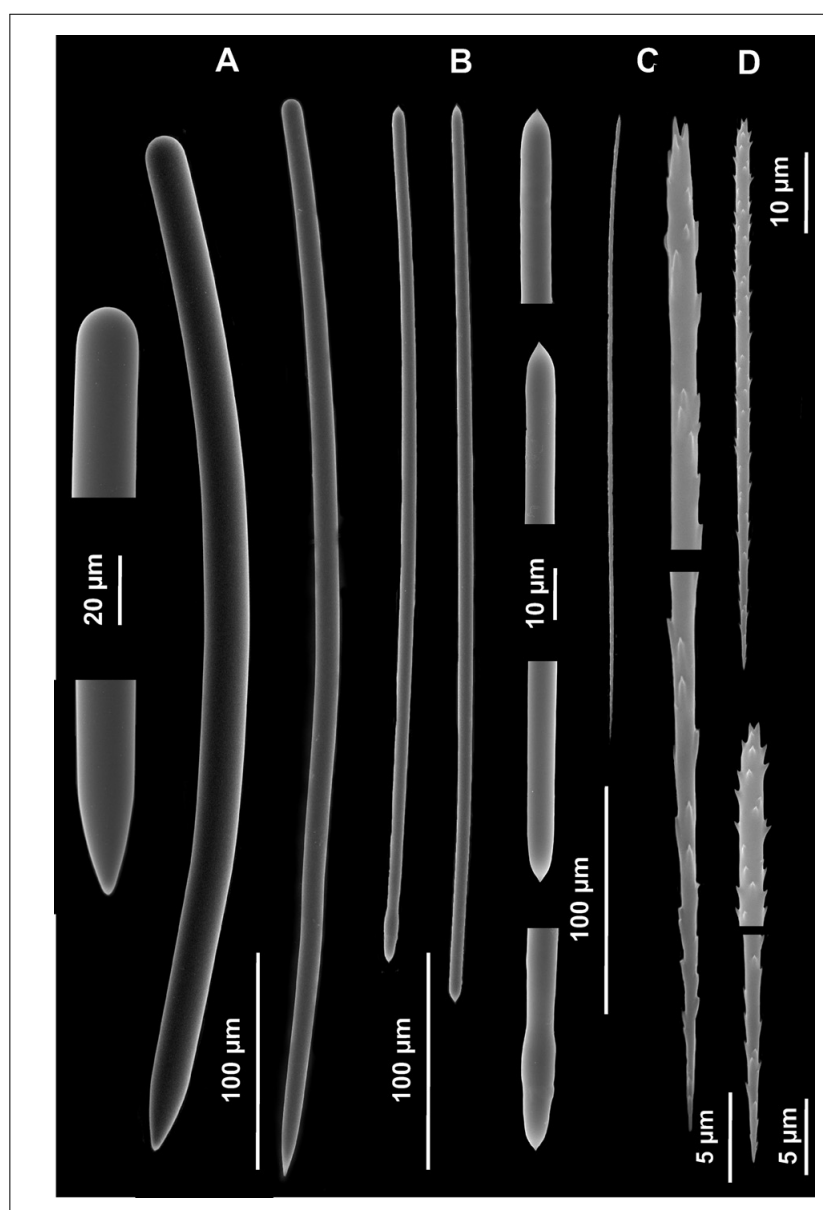

FIGURE 6 | Spicules of Tedania (Tedaniopsis) phacellina, Topsent, 1912. (Holotype) as seen with a Scanning Electron Microscope. (A) Styles. (B) Tornotes. (C) Onychaetes I. (D) Onychaetes II. 

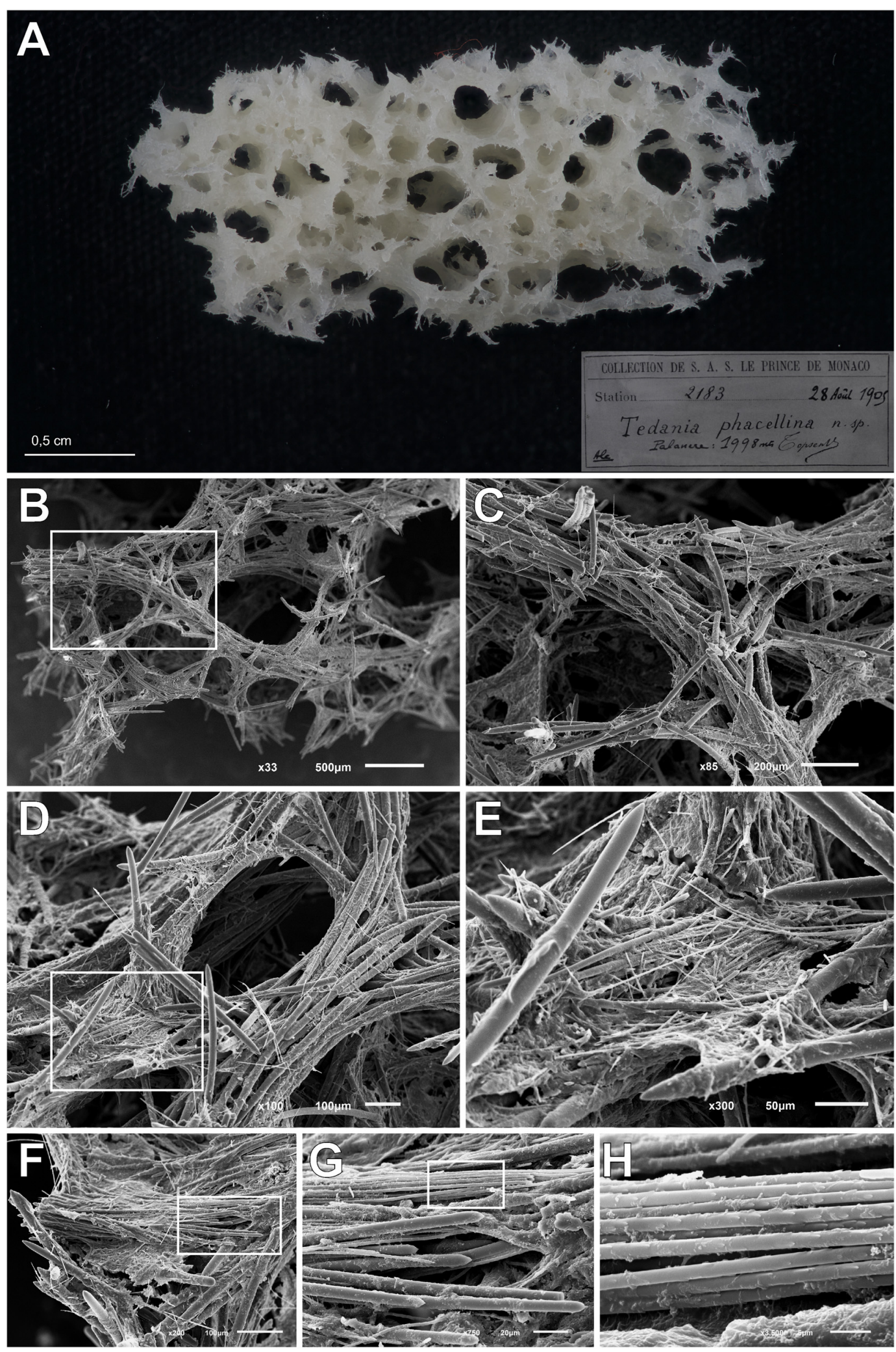

FIGURE 7| Tedania (Tedaniopsis) phacellina, Topsent, 1912. (A) Schyzotype, the small fragment extract from the holotype used in this paper. (B,C) Section of choanosomal skeleton where the bundles of styles can be seen. (D,E) Skeleton around the aquiferous system composed of multispicular tracts and styles; onychaetes covering the tracts and imbibed in the spongin can be seen. $\mathbf{( F , G ) ~ B u n d l e s ~ o f ~ e c t o s o m a l ~ t o r n o t e s . ~} \mathbf{( H )}$ Onychaetes in trichodragmata. 
Tedania is present in all oceans except Antarctica where the subgenus that predominates is Tedaniopsis (19 spp.). The distribution of Tedania (Stylotedania) folium Van Soest, 2017 is the tropical-Atlantic Guyana shelf (Figures 8, 9).
With respect to the northern hemisphere, the subgenus Tedania is represented by 26 species. The most abundant is Tedania (Tedania) ignis (Duchassaing de Fonbressin and Michelotti, 1864) frequent in both hemispheres, from the Bermudas in the north to Santa Catarina, southeast Brazil, Belize

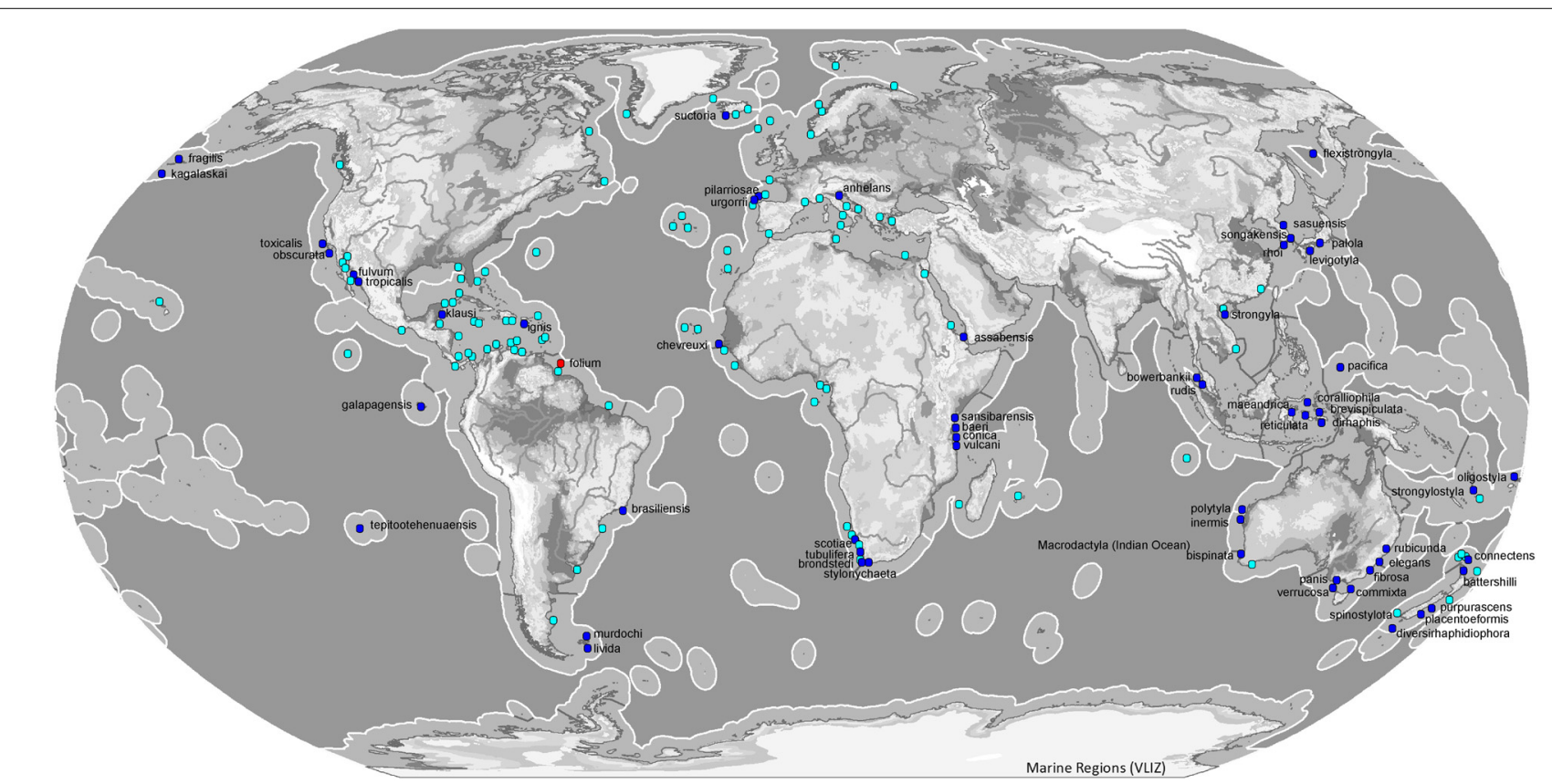

FIGURE 8 | Map of ecoregions (Spalding et al., 2007) showing the global diversity and distribution of the subgenus Tedania (blue marine dots for holotypes, light blue dots other records) and Stylotedania (red dot holotype) based on data derived from the World Porifera Database 2020.

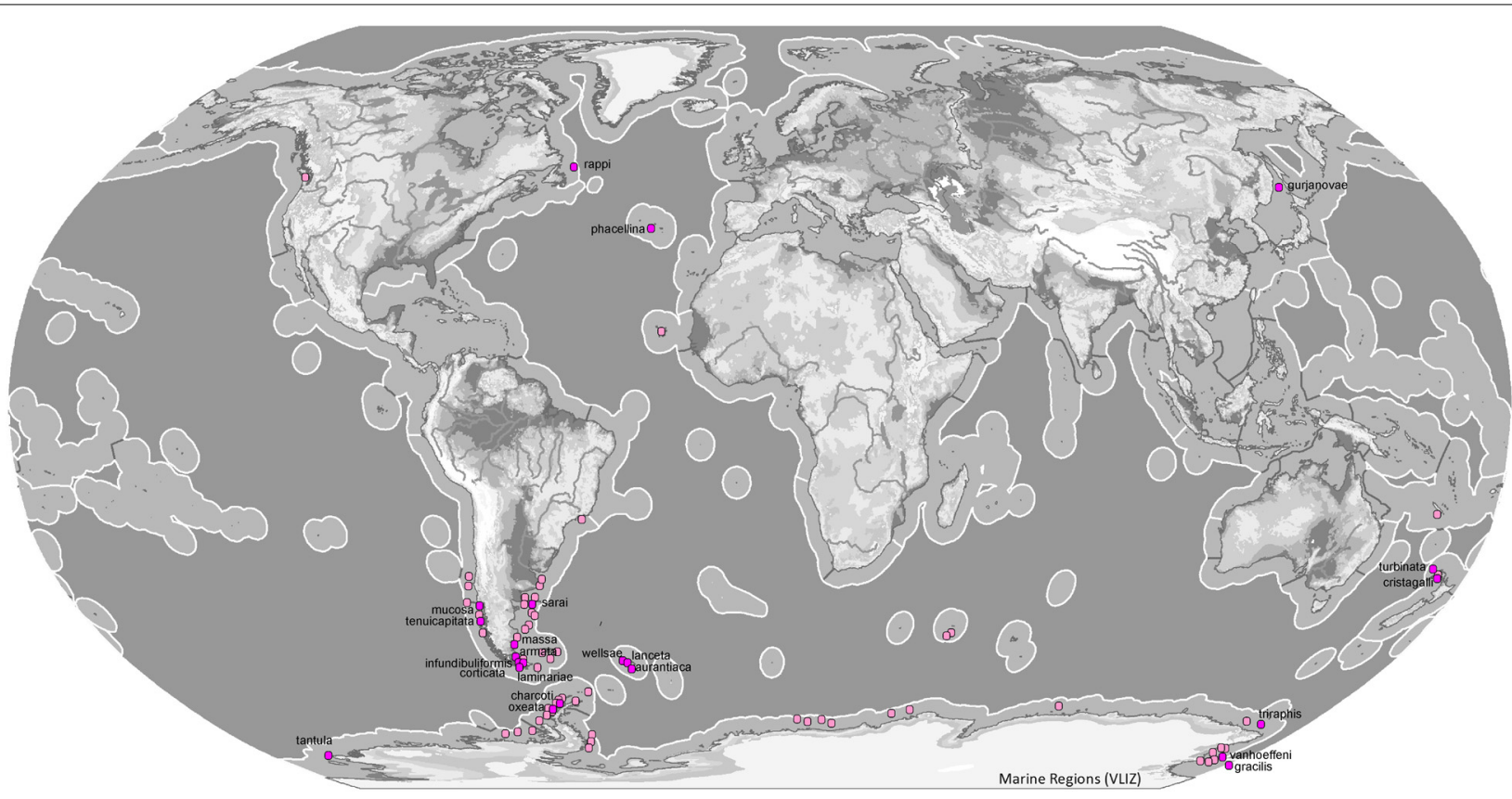

FIGURE 9 | Map of ecoregions (Spalding et al., 2007) showing the global diversity and distribution of the subgenus Tedaniopsis (purple dots for holotypes, pinks dots for other records) based on data derived from the World Porifera Database 2020 combined with the new data from the present study. 
in the west and Fernando de Noronha, northeast of Brazil. The species was first noted in Hawaii in 1950 (Núñez-Pons et al., 2017). The occurrence of this species includes the Tropical Atlantic, Temperate South America and Eastern Indo-Pacific ecoregions (Spalding et al., 2007). Tedania (Tedania) suctoria Schmidt, 1870, has a wide distribution in both ecoregions and one more. From the Kola Fiord (Breitfuss, 1912) and Davis Strait (Murillo et al., 2018)in the Arctic to Cape Vert in the Tropical Atlantic ecoregion (Topsent, 1928) and the Azores (Topsent, 1904, 1928) in the Temperate North Atlantic ecoregion. Tedania (Tedania) anhelans (Vio G in Olivi,, 1792) is one of the most common species, distributed from the Celtic Seas in the north to the Gulf of Guinea in the south, the Azores in the west and the Levantine Sea in the east. Other species that live in the Temperate Northern Atlantic waters are Tedania (Tedania) pilarriosae Cristobo, 2002 and Tedania (Tedania) urgorrii Cristobo, 2002.

In the northern hemisphere the subgenus Tedaniopsis has been represented until now by two species: Tedania (Tedaniopsis) phacellina Topsent, 1912 in the Azores (Temperate Northern Atlantic) and Tedania (Tedaniopsis) gurjanovae Koltun, 1958 in Tatar Strait (Koltun, 1959) and San Juan Archipelago (Bakus, 1964) in the Temperate Northern Pacific ecoregion.

In summary, the main differences found between $T$. (T.) rappi (Tr) and $T$. (T.) phacellina (Tp) are the very different habitus -arborescent ( $\mathrm{Tr}$ )/massive (Tp)-(Figure 2), coanosomal skeletal arrangement -paucispicular $(\mathrm{Tr}) /$ multispicular tracts (Tp)-(Figures 3, 4, 7); styles thickness -double in Tp-. Head terminations of tornotes -mucronate ( $\mathrm{Tr})$ /conical (Tp) with the ends somewhat swallowed in $\mathrm{Tr}-$. The onychaetes have short spines (Tr) and the base is blunt (Figures 5, 6).

In fact, the new Tedania (Tedaniopsis) rappi is the first species of this subgenus in the Arctic ecoregion as defined by Spalding et al. (2007). It was found not infrequently in an area closed to protect vulnerable marine ecosystems from the impacts of bottom contact fishing and in a CBD EBSA, the latter conferring enhanced motivation to identify and adopt appropriate measures for conservation and sustainable use by all industrial sectors. The identification of this unique species may warrant including the area in networks of marine protected areas in accordance with international law.

\section{DATA AVAILABILITY STATEMENT}

The datasets generated for this study can be found in the online repositories. The names of the repository/repositories and accession number(s) can be found below: ZooBank (urn:lsid:zoobank.org:act:4535FF69-E29C-4C2B-B47F-EC78117 C8F2C).

\section{REFERENCES}

Aguilar-Camacho, J. M., Carballo, J. L., and Cruz-Barraza, J. A. (2018). Tedania (Porifera: Demospongiae: Poecilosclerida) from the Mexican Pacific with the description of two new species. J. Nat. Hist. 52, 1311-1332.

Bakus, G. J. (1964). Morphogenesis of Tedania gurjanovae Koltun(Porifera). Pacif. Sci. 18, 58-63.

\section{AUTHOR CONTRIBUTIONS}

EK and JC acquired the funding. LB and TC conducted the sampling. PR, EB, TC, and JC identified the fauna. JC and $\mathrm{PR}$ made the figures and tables with help from LB for Figure 1. All authors conceived and designed the study, reviewed drafts of the manuscript, and helped to write the manuscript.

\section{FUNDING}

This research has been performed in the scope of the SponGES project, which received funding from the European Union's Horizon 2020 Research and Innovation Programme under Grant Agreement No. 679849 and the European Research project ICY-LAB (ERC-2015-STG Grant Agreement No. 678371). Canadian field work was supported through Fisheries and Oceans Canada (DFO) International Governance Strategy (IGS) funded by EK and with DFO ship time allocated to EK.

\section{ACKNOWLEDGMENTS}

We would like to thank the captain and crew of CCGS Hudson and the Canadian Scientific Submersible Facility (CSSF) ROV team, for support during the Hudson 2010-029 mission. We would also like to thank the Principal Investigator Kate Hendry and Claire Goodwin, together with the captain, crew, and scientific party of the ICY-LAB expedition DY081. Also Camille Lirette (DFO, Canada) for send photos and frame grabs from ROPOS 2010 cruise dive 1340 and to Marieve Bouchard Marmen (DFO, Canada) for arranging the shipment of the holotype of T. (T.) rappi to be sent to the Canadian Museum of Nature (CMN) in Otawa. We thank J. M. Gagnon, CMN for his acceptance and rapid cataloging of that holotype. Technical assistance was obtained from our IEO colleagues Alejandra Calvo, from Marseille colleagues, Sandrine Chenesseau, and Jean Vacelet and Sergio Taboada from the Natural History Museum of London, who has worked in the DNA extraction and amplification of the holotype. We thank to Victor Vega (Universidad Oviedo) for his technical assistance during SEM image acquisition. Our most sincere thanks also, to Michelle Bruni of the Monaco Oceanographic Museum for her agile efforts and response for the revision of the holotype of T. phacelina. We are also grateful to the two reviewers for their valuable and constructive comments to previous version of this manuscript.

Bergquist, P. R., and Fromont, P. J. (1988). The marine fauna of New Zealand: Porifera, Demospongiae, Part 4 Poecilosclerida. New Zealand Ocean. Inst. Mem. 96, 1-197. doi: 10.1007/978-3-319-23 534-9_1

Bertolino, M., Schejter, L., Calcinai, B., Cerrano, C., and Bremec, C. (2007). "Sponges from a submarine canyon of the Argentine sea," in Porifera Research. Biodiversity, Innovation and Sustainability. Livros de Museu Nacional 28, eds 
M. R. Custódio, G. Lôbo-Hajdu, E. Hajdu, and G. Muricy (Rio de Janeiro), 189-201.

Bowerbank, J. S. (1858). On the anatomy and physiology of the spongiadae. part i. on the Spicula. Philos. T. Roy. Soc. 148, 279-332. doi: 10.1098/rstl.1858.0016

Breitfuss, L. L. (1912). Zur Kenntniss der Spongio-Fauna des Kola Fjords. Trav. Soc. Imp. Nat. St. Pet. Sec. Zool. 41I-II, 61-80.

Cárdenas, P., Pérez, T., and Boury-Esnault, N. (2012). "Sponge systematics facing new challenges," in Advances in Sponge Science: Phylogeny, Systematics, Ecology. Advances in Marine Biology, Vol. 61, eds M. A. Becerro, M. J. Uriz, M. Maldonado, X. Turon. 79-209. doi: 10.1016/b978-0-12-387787-1.00010-6

Cárdenas, P., and Rapp, H. T. (2012). A review of Norwegian streptaster-bearing Astrophorida (Porifera: Demospongiae: Tetractinellida), new records and a new species. Zootaxa 52, 1-52. doi: 10.11646/zootaxa.3253.1.1

Cárdenas, P., Rapp, H. T., Schander, C., and Tendal, O. S. (2010). Molecular taxonomy and phylogeny of the Geodiidae (Porifera, Demospongiae, Astrophorida) - combining phylogenetic and Linnaean classification. Zool. Scr. 39, 89-106. doi: 10.1111/j.1463-6409.2009.00402.x

Carter, H. J. (1876). Descriptions and figures of deep-sea sponges and their spicules, from the atlantic ocean, dredged up on board H.M.S.'Porcupine', chiefly in 1869 (concluded). Ann. Mag. Nat. Hist. 18, 226-240. doi: 10.1080/ 00222937608682035

Convention on Biological Diversity (2015). Ecologically or Biologically Significant Areas (EBSAs) Orphan Knoll. Avaliable at: https://chm.cbd.int/database/record? documentID=204103 (accessed September 15, 2020).

Cristobo, F. J. (2002). The Genus Tedania (Porifera, Demospongiae, Poecilosclerida) in the waters of the iberian peninsula (Northeast Atlantic) with a description of two new Species. Sarsia 87, 362-377. doi: 10.1080/0036482021000155815

Cristobo, F. J., and Urgorri, V. (2001). Revision of the genus Trachytedania (Porifera: Poecilosclerida) with a description of Trachytedania ferrolensis sp. nov. from the north-east Atlantic. J. Mar. Biol. Ass. 81, 569-579. doi: 10.1017/ s0025315401004258

Cristobo, J., Urgorri, V., Solorzano, M. R., and Ríos, P. (1993). Métodos de recogida, estudio y conservación de las colecciones de poríferos. Int. Symp. First World Cong. Preserv. Conserv. Nat. Hist. Coll. 2, 277-287.

Dendy, A. (1924). Porifera. Part I. non-antarctic sponges. natural history report. british antarctic (Terra Nova) Expedition, 1910. Zoology 6, 269-392.

Desqueyroux-Faúndez, R., and Van Soest, R. W. M. (1996). A review of Iophonidae, Myxillidae and Tedaniidae occurring in the South East Pacific (Porifera: Poecilosclerida). Rev. Suisse. Zool. 103, 3-79. doi: 10.5962/bhl.part.79938

Duchassaing de Fonbressin, P., and Michelotti, G. (1864). Spongiaires de la mer Caraibe. Natuurkundige verhandelingen van de Hollandsche maatschappij der wetenschappen te Haarlem. Natuurkundige verhandelingen van de Hollandsche maatschappij der wetenschappen te Haarlem 21, 1-124.

Duplessis, K., and Reiswig, H. M. (2004). Three new species and a new genus of Farreidae (Porifera: Hexasterophora: Hexactinosida). Proc. Biol. Soc. Wash. 117, 199-212.

Giribet, G., and Wheeler, W. C. (2001). Some unusual small-subunit ribosomal RNA sequences of metazoans. Am. Museum Novit. 3337, 1-16. doi: 10.1206/ 0003-00822001337<0001:SUSSRR<2.0.CO;2

Grant, R.E. (1836). "Animal kingdom," in The Cyclopaedia of Anatomy and Physiology, Vol. 1, ed. R. B. Todd ( London: Sherwood, Gilbert, and Piper), $1-813$.

Goodwin, C., Brewin, P. E., and Brickle, P. (2012). Sponge biodiversity of South Georgia island with descriptions of fifteen new species. Zootaxa 3542, 1-48. doi: 10.11646/zootaxa.3542.1.1

Gray, J. E. (1867). Notes on the arrangement of sponges, with the descriptions of some New Genera. Proc. Zool. Soc. Lond. 1867, 492-558.

Greenan, B. J. W., Yashayaev, I., Head, E. J. H., Harrison, W. G., Azetsu-Scott, K., Li, W. K. W., et al. (2010). Interdisciplinary Oceanographic Observations of Orphan Knoll. NAFO SCR Doc. 10/19. Serial No. N5774. Avaliable at: https://www.nafo. int/Portals/0/PDFs/sc/2010/scr10-019.pdf (accessed August 15, 2018).

Hansen, G. A. (1885). Spongiadae. the norwegian north-atlantic expedition 18761878. Zoology 13, 1-26. doi: 10.1080/00364827.1973.10411241

Hendry, K. R., Cassarino, L., Bates, S. L., Culwick, T., Frost, M., Goodwin, C., et al. (2019). Silicon isotopic systematics of deep-sea sponge grounds in the North Atlantic. Quaternary Sci. Rev. 210, 1-14. doi: 10.1016/j.quascirev.2019.02.017
Hentschel, E. (1914). Monaxone Kiesel schwämme und Hornschwämme der Deutschen Südpolar-Expedition 1901-1903. Deutsche Südpolar-Expedition 15, 35-141.

Hooper, J. N. A., and Van Soest, R. W. M. (eds) (2002). Systema Porifera. A Guide to the Classification of Sponges. New York, NY: Kluwer Academic, xix-xlviii. doi: 10.1007/978-1-4615-0747-5

Hooper, J. N. A., and Wiedenmayer, F. (1994). "Porifera," in Zoological Catalogue of Australia, ed. A. Wells (Melbourne: CSIRO), 12.

Kersken, D., Kocot, K., Janussen, D., Schell, T., Pfenninger, M., and Martínez Arbizu, P. (2018). First insights into the phylogeny of deep-sea glass sponges (Hexactinellida) from polymetallic nodule fields in the Clarion-Clipperton Fracture Zone (CCFZ), northeastern Pacific. Hydrobiologia 811, 283-293. doi: 10.1007/s10750-017-3498-3

Kirkpatrick, R. (1907). preliminary report on the monaxonellida of the national antarctic expedition. Ann. Mag. Nat. Hist. 7, 271-291. doi: 10.1080/ 00222930709487333

Koltun, V. M. (1958). [Cornacuspongia of sea waters washing the South Sakhalin and the South Kurile Island region.]. Issledovaniya dal'nevostochnÿkh morei SSR SSR. 5, 42-77.

Koltun, V. M. (1959). [Siliceous horny sponges of the northern and fareastern seas of the U.S.S.R.] [In Russian]. Opredeliteli po faune SSR, izdavaemye Zoologicheskim muzeem Akademii nauk. 67, 1-236.

Koltun, V. M. (1964). "Sponges of the Antarctic. 1Tetraxonida and Cornacuspongida," in Biological Reports of the Soviet Antarctic Expedition (1955-1958). Akademya Nauk SSSR [English translation,1966, Israel Program for Scientific Translation], eds E. P. Pavlovskii, A. P. Andriyashev, and P. V. Ushakov 6-133,443-448.

Meredyk, S. P. (2017). Physical Characterization and Benthic Megafauna Distribution and Species Composition on Orphan Knoll and Orphan Seamount, NW Atlantic. Masters thesis, Memorial University of Newfoundland, St. John's, NL.

Meredyk, S. P., Edinger, E., Piper, D. J. W., Huvenne, V. A. I., Hoy, S., and Ruffman, A. (2020). Enigmatic deep-water mounds on the orphan knoll. Labrador Sea. Front. Mar. Sci. 6:744. doi: 10.3389/fmars.2019.00744

Morrow, C., and Cárdenas, P. (2015). Proposal for a revised classification of the Demospongiae (Porifera). Front. Zool. 12:7. doi: 10.1186/s12983-015-0099-8

Morrow, C. C., Picton, B. E., Erpenbeck, D., Boury-Esnault, N., Maggs, C. A., and Allcock, A. L. (2012). Congruence between nuclear and mitochondrial genes in Demospongiae: a new hypothesis for relationships within the G4 clade (Porifera: Demospongiae). Mol. Phylogen. Evol. 62, 174-190. doi: 10.1016/j.ympev.2011. 09.016

Murillo, F. J., Kenchington, E., Tompkins, G., Beazley, L., Baker, E., Knudby, A., et al. (2018). Sponge assemblages and predicted archetypes in the eastern Canadian Arctic. Mar. Ecol. Prog. Ser. 597, 115-135. doi: 10.3354/meps 12589

Murillo, F. J., Tabachnick, K. R., and Menshenina, L. L. (2013). Glass Sponges off the Newfoundland (Northwest Atlantic): Description of a New Species of Dictyaulus (Porifera: Hexactinellida: Euplectellidae). J. Mar. Biol. 2013:438485. doi: $10.1155 / 2013 / 438485$

NAFO (2016). Potential Vulnerable Marine Ecosystems Impacts of DeepSea Fisheries. Avaliable at: https://www.nafo.int/Portals/0/PDFs/NEREIDA/ diptico-nereida.pdf?ver=2016-08-09-104633-013 (accessed January 7, 2021).

Núñez-Pons, L., Calcinai, B., and Gates, R. D. (2017). Who's there? - First morphological and DNA barcoding catalogue of the shallow Hawaiian sponge fauna. PLoS One 12:e0189357. doi: 10.1371/journal.pone.0189357

Rapp, H. T. (2006). Calcareous sponges of the genera Clathrina and Guancha (Calcinea, Calcarea, Porifera) of Norway (north-east Atlantic) with the description of five new species. Zool. J. Linn. Soc. Lon. 147, 331-365. doi: 10.1111/j.1096-3642.2006.00221.x

Ridley, S. O., and Dendy, A. (1886). Preliminary report on the Monaxonida collected by H.M.S. Challenger. Part I. Ann. Mag. Nat. Hist. 18, 325-351. doi: $10.1080 / 00222938609459982$

Ridley, S. O. (1881). "XI. Spongida. Horny and Siliceous Sponges of Magellan Straits, S.W. Chili, and Atlantic off SW Brazil," in Account of the Zoological Collections made during the Survey of H.M.S. 'Alert' in the Straits of Magellan and on the Coast of Patagonia, ed. A. Gunther (Proceedings of the Zoological Society of London), 107-141. 
Sarà, M. (1978). Demospongie di acquesuperficialidella Terra del Fuoco (Spedizioni AMF Mares-GRSTS e SAI). Boll. Mus. Ist. Biol. Univ. Genova. 46, 7-117.

Schmidt, O. (1870). Grundzüge Einer Spongien-Fauna des atlantischen Gebietes, Vol. iii-iv. Leipzig: Wilhelm Engelmann, 1-88.

Sollas, W. J. (1880). The sponge-fauna of Norway; a report on the Rev. A.M. Norman's collection of sponges from the norwegian coast. Ann. Mag. Nat. Hist. 5, 130-144.

Sollas, W. J. (1885). A Classification of the Sponges. Ann. Mag. Nat. His. 16:395.

Spalding, M. D., Fox, H. E., Allen, G. R., Davidson, N., Ferdaña, Z. A., Finlayson, M., et al. (2007). Marine ecoregions of the world: a bioregionalization of coastal and shelf areas. BioScience 57, 573-583. doi: 10.1641/b570707

Stephens, J. (1915). Sponges of the coasts of Ireland. I.-the triaxonia and part of the Tetraxonida. Fis. Ireland Sci. Invest. 1914, 1-43.

Tabachnick, K. R., and Menshenina, L. L. (2007). Revision of the genus Asconema (Porifera: Hexactinellida: Rossellidae). J. Mar. Biolog. Assoc. U.K. 87, $1403-$ 1429. doi: 10.1017/S0025315407058158

Topsent, E. (1904). Spongiaires des Açores. Résultats des campagnes scientifiques accomplies par le Prince Albert I. Monaco 25, 1-280.

Topsent, E. (1907). Poecilosclérides nouvelles recueillies par le Français dans l'Antarctique. B. Mus. Natl. Hist. Nat. Paris 13, 69-76.

Topsent, E. (1912). Sur une grande Tedania abyssale des Açores (Tedania phacellina, n. sp.). Bulletin de l'Institut océanographique, Monaco. 252, 1-7. doi: 10.1007/978-3-319-23534-9_1

Topsent, E. (1913). Spongiaires provenant des campagnes scientifiques de la 'Princesse Alice' dans les Mers du Nord (1898-1899 - 1906-1907). Résultats des Campagnes Scientifiques Accomplies par le Prince Albert I de Monaco. 45, 1-67.

Topsent, E. (1928). Spongiaires de l'Atlantique et de la Méditerranée provenant des croisières du Prince Albert ler de Monaco. Résultats des campagnes scientifiques accomplies par le Prince Albert I. Monaco 74, 1-376.

Van Soest, R. W. M. (2002). "Family Tedaniidae Ridley \& Dendy, 1886," in Systema Porifera. A Guide to the Classification of Sponges. 1, eds J. N. A. Hooper and
R. W. M. Van Soest (New York, NY: Kluwer Academic), 625-632. doi: 10.1007/ 978-1-4615-0747-5 66

Van Soest, R. W. M. (2017). Sponges of the Guyana Shelf. Zootaxa 4217, 1-225. doi: 10.11646/zootaxa.4217.1.1

Van Soest, R. W. M., Boury-Esnault, N., Hooper, J. N. A., Rützler, K., de Voogd, N. J., Alvarez, B., et al. (2021). World Porifera Database. Accessed at http://www.marinespecies.org/porifera (accessed January 8, 2021).

Vio G in Olivi, , G. (1792). Letter on sponges From the Gulf of Smyrna, Chap. Bassano. Zoologia Adriatica, xi-xxxi.

Von Lendenfeld, R. (1888). Descriptive Catalogue of the Sponges in the Australian Museum, Sidney, Vol. i-xiv. London: Taylor \& Francis, $1-260$.

Vosmaer, G. C. J. (1885). The sponges of the 'willem Barents' expedition 1880 and 1881. Bijdragen tot de Dierkunde 12, 1-47.

Wudrick, A., Beazley, L., Culwick, T., Goodwin, C., Cárdenas, P., Xavier, J., et al. (2020). A pictorial guide to the epibenthic megafauna of orphan knoll (northwest Atlantic) identified from in situ benthic video footage. Can. Tech. Rep. Fish. Aquat. Sci. 3375:154.

Conflict of Interest: The authors declare that the research was conducted in the absence of any commercial or financial relationships that could be construed as a potential conflict of interest.

Copyright (c) 2021 Ríos, Cristobo, Baker, Beazley, Culwick and Kenchington. This is an open-access article distributed under the terms of the Creative Commons Attribution License (CC BY). The use, distribution or reproduction in other forums is permitted, provided the original author(s) and the copyright owner(s) are credited and that the original publication in this journal is cited, in accordance with accepted academic practice. No use, distribution or reproduction is permitted which does not comply with these terms. 